\title{
Assessment of Continuous Gas Resources in the Khorat Plateau Province, Thailand and Laos, 2016
}

Using a geology-based assessment methodology, the U.S. Geological Survey assessed mean undiscovered, technically recoverable resources of 2.3 trillion cubic feet of continuous gas in the Khorat Plateau Province of Thailand and Laos.

\section{Introduction}

The U.S. Geological Survey (USGS) completed a geologybased assessment of undiscovered, technically recoverable shale-gas and tight-gas resources in the Khorat Plateau Province of northeast Thailand and western Laos (fig. 1). The Khorat Plateau Province is part of Sundaland, a geologically complex continental area that consists of several terranes that originated from the northern margin of the supercontinent Gondwana and accreted to Eurasia from the late Paleozoic through the Mesozoic (Barber and others, 2011; Metcalfe, 2011; Morley, 2012; Hall, 2013; Morley and others, 2013). Progressive accretion of several Gondwanan blocks resulted in a mosaic of terranes, suture zones, accretionary wedges, and arc rocks that record a complex geologic history that may have affected the development and preservation of viable petroleum systems. Petroleum source rocks were deposited in extensional basins formed in the late Carboniferouslate Permian and Late Triassic (Booth and Sattayarak, 2011; Racey, 2011). Upper Carboniferous-upper Permian source rocks are marine shales, carbonaceous shales, and coals; Triassic source rocks are organic-rich, deep-basin lacustrine shales. Burial history modeling suggests that petroleum residing in potential tight (low permeability) sandstone or shale reservoirs entered the thermal window for dry gas during Late Jurassic-Early Cretaceous burial by more than 5 kilometers of Khorat Group rocks. Both source-rock intervals were exposed to several phases of deformation, uplift, and erosion that may have adversely affected the retention of gas in tight sandstones, siltstones, and shale reservoirs. This assessment quantifies the volumes of gas potentially retained within lacustrine shales of the Triassic Kuchinarai Group and gas potentially retained within tight-clastic reservoirs of the Triassic through Lower Cretaceous (Koysamran and ComrieSmith, 2011). Shows of gas from tight rock have been reported from wells in the Khorat Plateau Province (Booth, 1998; Malila, 2011; Racey, 2011), but there are no reports of recoverable gas from shales (Chumkratoke and Dunn-Norman, 2015).

\section{Total Petroleum Systems and Assessment Units}

For the Khorat Plateau Province, the USGS defined two total petroleum systems. The Triassic Kuchinarai Total Petroleum System was defined to include gas that was generated and potentially retained within synrift lacustrine organic-rich shales of the Triassic Kuchinarai Group (fig. 2). The Khorat Kuchinarai Shale Gas Assessment Unit (AU), the Sakon Nakhon Kuchinarai Shale Gas AU, the Phu Phan Kuchinarai Shale Gas AU, and the Savannakhét

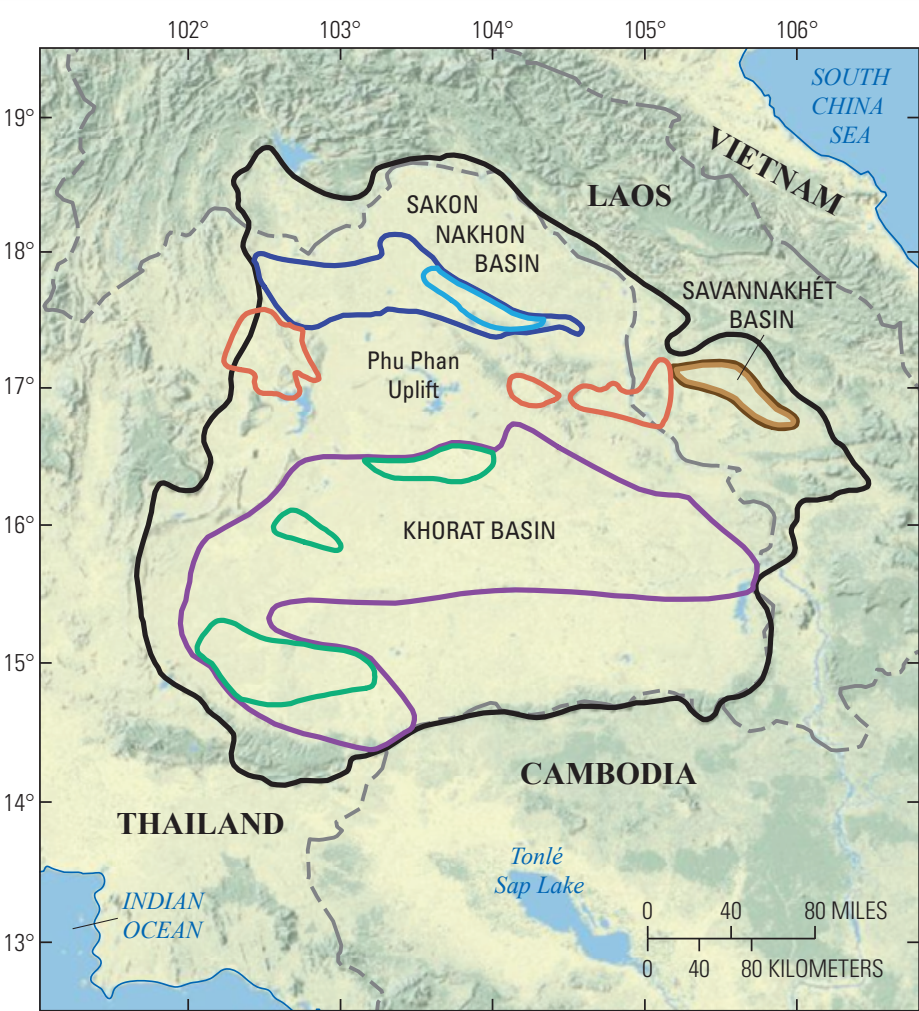

Source: U.S. Department of the Interior National Park Service
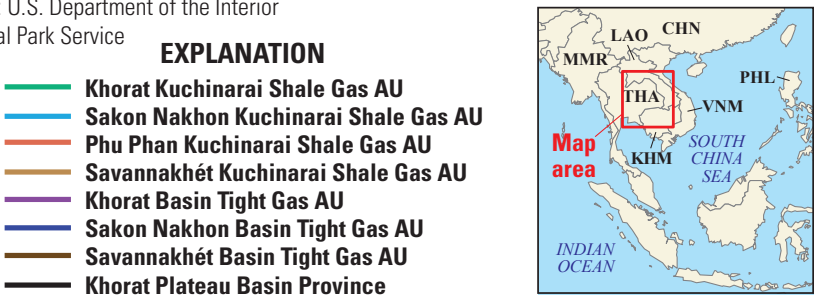

Figure 1. Map showing the location and boundaries of the Khorat Plateau Province, Thailand and Laos, and the seven continuous assessment units (AUs) defined for this study.

Kuchinarai Shale Gas AU were defined within this TPS. The Upper Carboniferous-Triassic Composite Total Petroleum System was defined to include gas that is potentially retained within tight-clastic reservoirs of the Upper Triassic, Jurassic, and Cretaceous. The Khorat Basin Tight Gas AU, the Sakon Nakhon Basin Tight Gas AU, and the Savannakhét Basin Tight Gas AU were defined within this TPS. Assessment unit boundaries were developed using published maps depicting Permian and Triassic depocenters (Booth and Sattayarak, 2011). We 


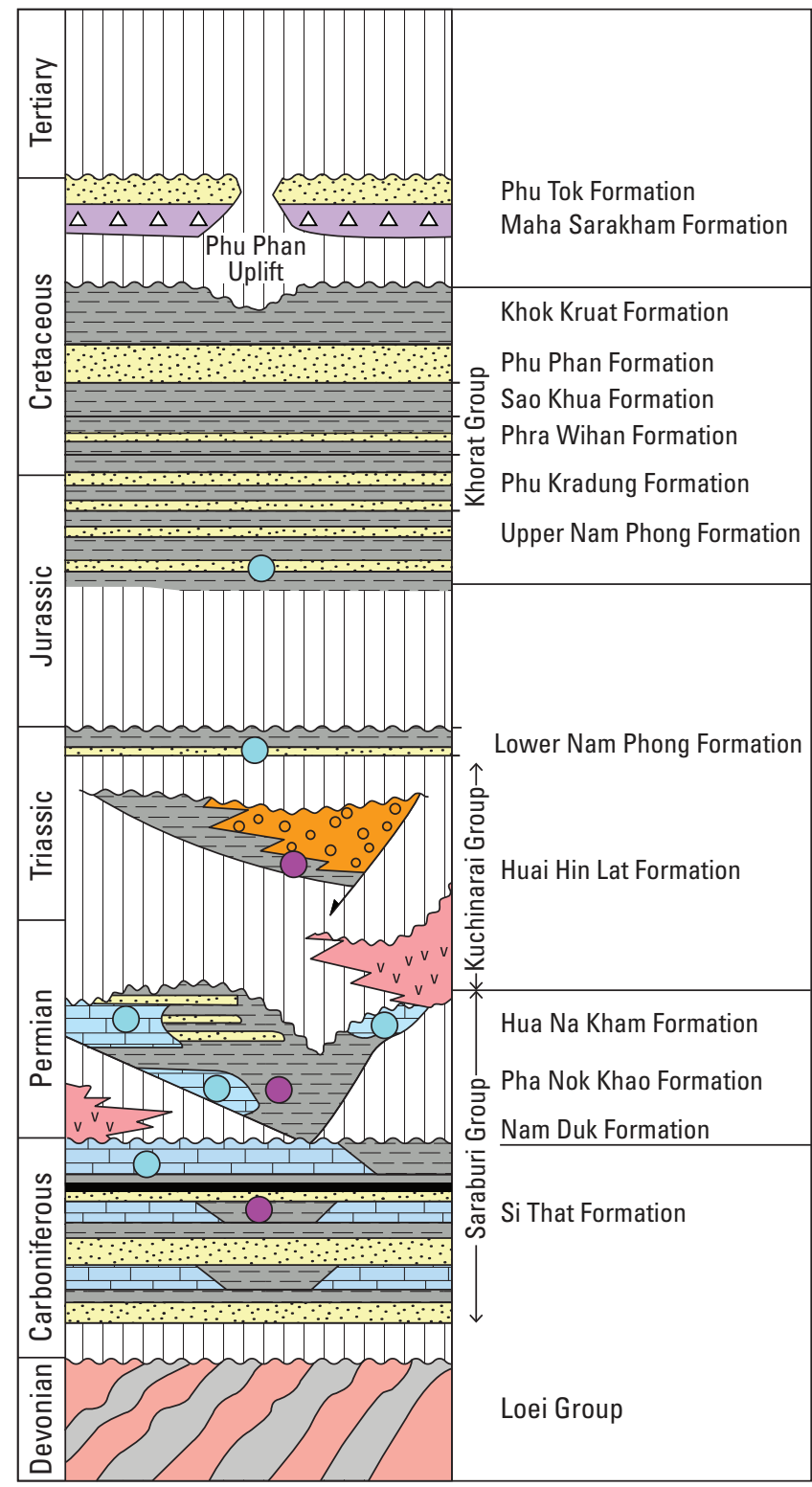

\section{EXPLANATION}

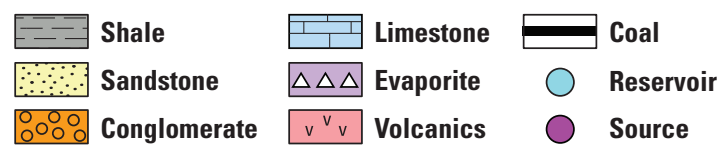

Figure 2. Stratigraphy of the Khorat Plateau Province, Thailand and Laos (modified from Koysamran and Comrie-Smith, 2011). recognize that there were three episodes of basin formation in the province, but the AUs were named using the present geomorphic elements of Khorat Basin, Sakon Nakhon Basin, Phu Phan Uplift, and Savannakhét Basin. Assessment input data for seven continuous AUs are shown in table 1. Well drainage areas, estimated ultimate recoveries, and success ratios were taken from U.S. shale-gas and tight-gas analogs.

\section{Undiscovered Resources Summary}

In the Khorat Plateau Province, the USGS quantitatively assessed total mean undiscovered, technically recoverable shale-gas and tight-gas resources of 2,301 billion cubic feet of gas (BCFG), or 2.3 trillion cubic feet of gas, with an F95-F5 range from 0 to 9,268 BCFG and 17 million barrels of natural gas liquids (MMBNGL) with an F95-F5 range from 0 to 67 MMBNGL (table 2). For undiscovered, technically recoverable shale-gas resources, the mean total is 586 BCFG with an F95-F5 range from 0 to 2,150 BCFG, and 6 MMBNGL with an F95-F5 range from 0 to 19 MMBNGL. For undiscovered tight-gas resources, the mean total is 1,715 BCFG with an F95-F5 range from 0 to 7,118 BCFG and 11 MMBNGL with an F95-F5 range from 0 to 48 MMBNGL. The wide ranges of estimated undiscovered gas resources reflect the level of geologic uncertainty on the retention of gas within tight clastic reservoirs and shale reservoirs given the tectonic history. For gas accumulations, zeros at F95 reflect the chance that continuous gas might not exist in the AU, and the geologic AU probability (risk) was estimated to be less than one.

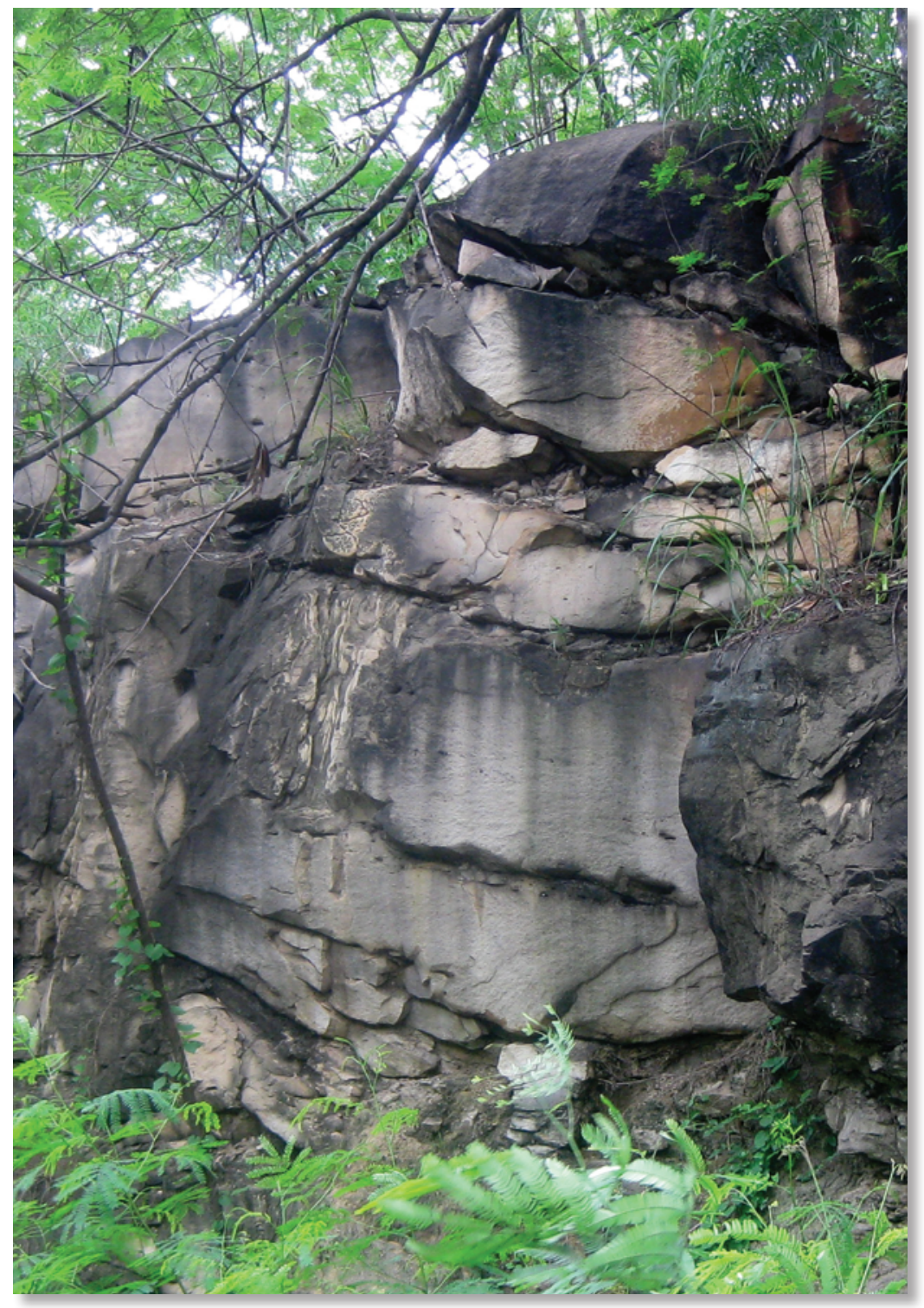


Table 1. Key assessment input data for seven continuous assessment units in the Khorat Plateau Basin Province, Thailand and Laos.

[AU, assessment unit; \%, percent; EUR, estimated ultimate recovery per well; BCFG, billion cubic feet of gas. EUR, well drainage area, and success ratios are from U.S. shale-gas and tight-gas analogs. The average EUR input is the minimum, median, maximum, and calculated mean. Shading indicates not applicable]

\begin{tabular}{|c|c|c|c|c|c|c|c|c|}
\hline \multirow{2}{*}{$\begin{array}{l}\text { Assessment input data- } \\
\text { Continuous AUs }\end{array}$} & \multicolumn{4}{|c|}{ Khorat Kuchinarai Shale Gas AU } & \multicolumn{4}{|c|}{ Sakon Nakhon Kuchinarai Shale Gas AU } \\
\hline & Minimum & Mode & Maximum & Calculated mean & Minimum & Mode & Maximum & Calculated mean \\
\hline Potential production area of AU (acres) & 600 & 821,000 & $1,967,000$ & 929,533 & 600 & 187,000 & 374,000 & 187,200 \\
\hline Average drainage area of wells (acres) & 80 & 120 & 160 & 120 & 80 & 120 & 160 & 120 \\
\hline Success ratios $(\%)$ & 10 & 50 & 90 & 50 & 10 & 50 & 90 & 50 \\
\hline Average EUR (BCFG) & 0.04 & 0.1 & 0.8 & 0.138 & 0.04 & 0.1 & 0.8 & 0.138 \\
\hline AU probability & 0.6 & & & & 0.6 & & & \\
\hline \multirow{2}{*}{$\begin{array}{l}\text { Assessment input data- } \\
\text { Continuous AUs }\end{array}$} & \multicolumn{4}{|c|}{ Phu Phan Kuchinarai Shale Gas AU } & \multicolumn{4}{|c|}{ Savannakhét Kuchinarai Shale Gas AU } \\
\hline & Minimum & Mode & Maximum & Calculated mean & Minimum & Mode & Maximum & Calculated mean \\
\hline Potential production area of AU (acres) & 600 & 675,000 & $1,351,000$ & 675,533 & 600 & 249,000 & 498,000 & 249,200 \\
\hline Average drainage area of wells (acres) & 80 & 120 & 160 & 120 & 80 & 120 & 160 & 120 \\
\hline Success ratios $(\%)$ & 10 & 50 & 90 & 50 & 10 & 50 & 90 & 50 \\
\hline Average EUR (BCFG) & 0.04 & 0.08 & 0.4 & 0.098 & 0.04 & 0.08 & 0.4 & 0.098 \\
\hline AU probability & 0.6 & & & & 0.5 & & & \\
\hline \multirow{2}{*}{$\begin{array}{c}\text { Assessment input data- } \\
\text { Continuous AUs }\end{array}$} & \multicolumn{4}{|c|}{ Khorat Basin Tight Gas AU } & \multicolumn{4}{|c|}{ Sakon Nakhon Basin Tight Gas AU } \\
\hline & Minimum & Mode & Maximum & Calculated mean & Minimum & Mode & Maximum & Calculated mean \\
\hline Potential production area of AU (acres) & 600 & $1,303,000$ & $12,408,000$ & $4,570,533$ & 600 & 371,000 & $2,081,000$ & 817,533 \\
\hline Average drainage area of wells (acres) & 40 & 80 & 120 & 80 & 40 & 80 & 120 & 80 \\
\hline Success ratios $(\%)$ & 10 & 50 & 90 & 50 & 10 & 50 & 90 & 50 \\
\hline Average EUR (BCFG) & 0.04 & 0.08 & 0.4 & 0.098 & 0.04 & 0.08 & 0.4 & 0.098 \\
\hline AU probability & 0.5 & & & & 0.5 & & & \\
\hline \multirow{2}{*}{$\begin{array}{c}\text { Assessment input data- } \\
\text { Continuous AUs }\end{array}$} & \multicolumn{4}{|c|}{ Savannakhét Basin Tight Gas AU } & & & & \\
\hline & Minimum & Mode & Maximum & Calculated mean & & & & \\
\hline Potential production area of AU (acres) & 600 & 249,000 & 498,000 & 249,200 & & & & \\
\hline Average drainage area of wells (acres) & 40 & 80 & 120 & 80 & & & & \\
\hline Success ratios $(\%)$ & 10 & 50 & 90 & 50 & & & & \\
\hline Average EUR (BCFG) & 0.04 & 0.08 & 0.4 & 0.098 & & & & \\
\hline AU probability & 0.5 & & & & & & & \\
\hline
\end{tabular}

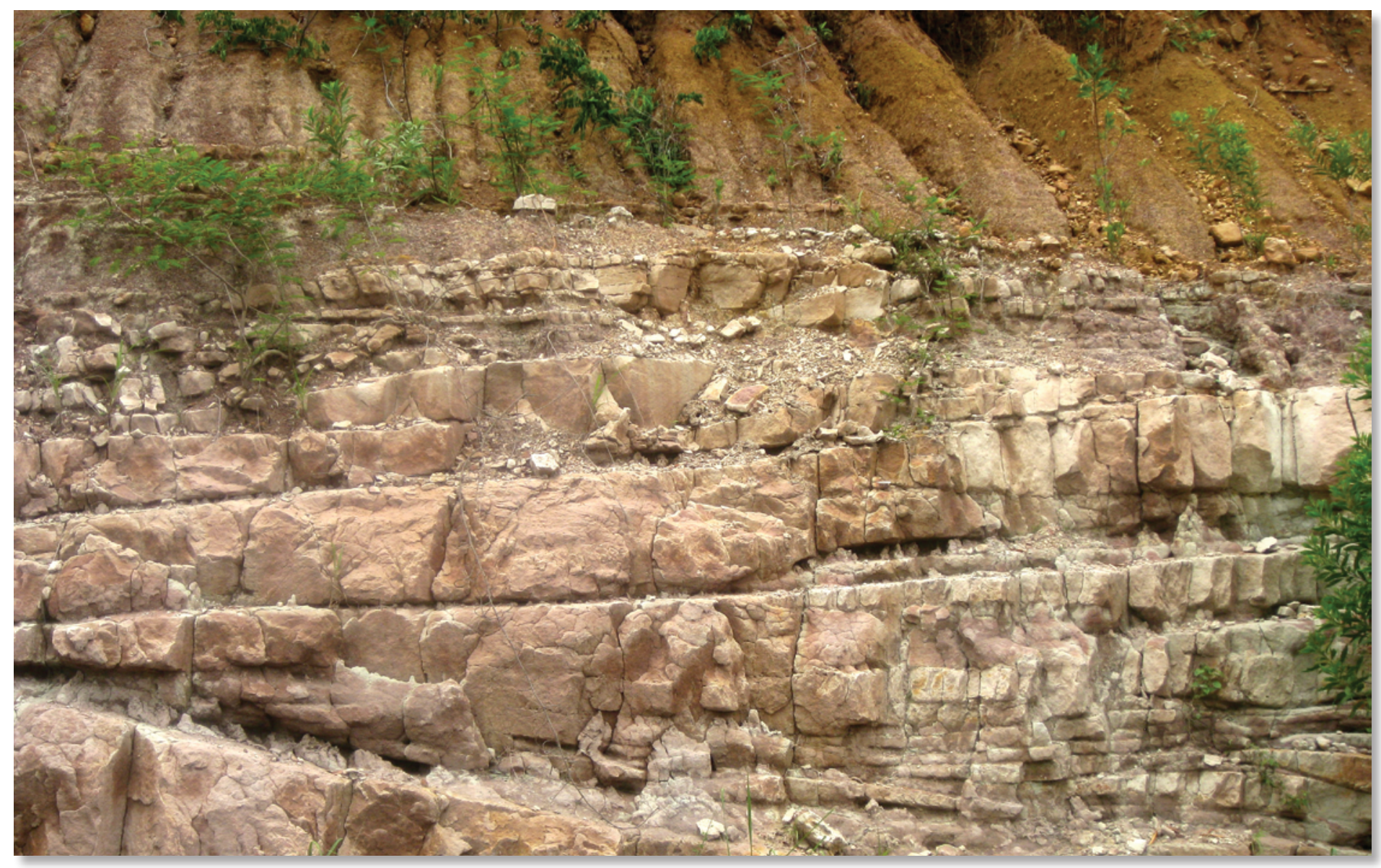

Lateral accretion surfaces and bedding in high-sinuosity fluvial channel sandstone of the Khorat Group along Highway 304, near kilometer marker 70. Sandstone is 5 meters thick. 
Table 2. Assessment results for seven continuous assessment units in the Khorat Plateau Basin Province, Thailand and Laos.

[BCFG, billion cubic feet of gas; NGL, natural gas liquids; MMBNGL, million barrels of natural gas liquids. Results shown are fully risked estimates. For gas accumulations, all liquids are included in the NGL category. F95 represents a 95-percent chance of at least the amount tabulated; other fractiles are defined similarly. Fractiles are additive under the assumption of perfect positive correlation. Shading indicates not applicable]

\begin{tabular}{|c|c|c|c|c|c|c|c|c|c|c|}
\hline \multirow{3}{*}{$\begin{array}{l}\text { Total petroleum systems } \\
\text { and assessment units (AUs) }\end{array}$} & \multirow{3}{*}{$\begin{array}{c}\text { AU } \\
\text { probability }\end{array}$} & \multirow{3}{*}{$\begin{array}{l}\text { Accumulation } \\
\text { type }\end{array}$} & \multicolumn{8}{|c|}{ Total undiscovered resources } \\
\hline & & & \multicolumn{4}{|c|}{ Gas (BCFG) } & \multicolumn{4}{|c|}{ NGL (MMBNGL) } \\
\hline & & & F95 & $\mathrm{F} 50$ & F5 & Mean & F95 & F50 & F5 & Mean \\
\hline \multicolumn{11}{|c|}{ Triassic Kuchinarai Total Petroleum System } \\
\hline Khorat Kuchinarai Shale Gas AU & 0.6 & Gas & 0 & 162 & 1,172 & 312 & 0 & 1 & 10 & 3 \\
\hline Sakon Nakhon Kuchinarai Shale Gas AU & 0.6 & Gas & 0 & 33 & 233 & 62 & 0 & 0 & 2 & 1 \\
\hline Phu Phan Kuchinarai Shale Gas AU & 0.6 & Gas & 0 & 105 & 554 & 162 & 0 & 1 & 5 & 1 \\
\hline Savannakhét Kuchinarai Shale Gas AU & 0.5 & Gas & 0 & 0 & 191 & 50 & 0 & 0 & 2 & 1 \\
\hline Total shale-gas resources & & & $\mathbf{0}$ & 300 & 2,150 & 586 & $\mathbf{0}$ & 2 & 19 & 6 \\
\hline \multicolumn{11}{|c|}{ Upper Carboniferous-Triassic Composite Total Petroleum System } \\
\hline Khorat Basin Tight Gas AU & 0.5 & Gas & 0 & 0 & 5,801 & 1,389 & 0 & 0 & 36 & 8 \\
\hline Sakon Nakhon Basin Tight Gas AU & 0.5 & Gas & 0 & 0 & 1,024 & 250 & 0 & 0 & 8 & 2 \\
\hline Savannakhét Basin Tight Gas AU & 0.5 & Gas & 0 & 0 & 293 & 76 & 0 & 0 & 4 & 1 \\
\hline Total tight-gas resources & & & $\mathbf{0}$ & $\mathbf{0}$ & 7,118 & 1,715 & $\mathbf{0}$ & $\mathbf{0}$ & 48 & 11 \\
\hline Total continuous resources & & & $\mathbf{0}$ & 300 & 9,268 & 2,301 & $\mathbf{0}$ & 2 & 67 & 17 \\
\hline
\end{tabular}

\section{References Cited}

Barber, A.J., Ridd, M.F., and Crow, M.J., 2011, The origin, movement, and assembly of the pre-Tertiary tectonic units of Thailand, in Ridd, M.F., Barber, A.J., and Crow, M.J., eds., The geology of Thailand: London, The Geological Society, p. 507-535.

Booth, J.E., 1998, The Khorat Plateau of NE ThailandExploration history and hydrocarbon potential, in The Seapex Exploration Conference, 17th Offshore South East Asia Conference and Exhibition, Singapore, December 2-3, 1998, Proceedings: Southeast Asia Petroleum Exploration Society, p. 169-203, accessed December 19, 2016, at http://www. seapex.org/document-download/.

Booth, J.E., and Sattayarak, Nares, 2011, Subsurface Carboniferous-Cretaceous geology of NE Thailand, chap. 9 of Ridd, M.F., Barber, A.J., and Crow, M.J., eds., The geology of Thailand: London, The Geological Society, p. 185-222.

Chumkratoke, C., and Dunn-Norman, S., 2015, Reservoir characteristics for unconventional shale play of Huai Hin Lat Formation in northeastern Thailand, in Society of Petroleum Engineers/Petroleum Engineering Association of Indonesia (IATMI [Ikatan Ahli Teknik Perminyakan Indonesia]) Asia Pacific Oil \& Gas Conference and Exhibition, October 20-22, 2015, Nusa Dua, Bali, Indonesia, Proceedings: Society of Petroleum Engineers, SPE-76474 015-MS, 12 p.

Hall, Robert, 2013, The paleogeography of Sundaland and Wallacea since the Late Jurassic: Journal of Limnology, v. 72 , no. 2 , p. $1-17$.
Koysamran, Suwisa, and Comrie-Smith, Nick, 2011, Basin modeling of Block L26/50, eastern Khorat Plateau, northeast Thailand, in The 4th Petroleum Forum-Approaching to the 21st Petroleum Concession Bidding Round, Chatuchak, Bangkok, Thailand, May 26-27, 2011, Proceedings: Department of Mineral Fuels, Ministry of Energy, p. 5-12, accessed April 11, 2017, at http:/www.dmf.go.th/cms/assets/1/The $\% 20$ 4th\%20(DMF)\%20Petroleum\%20Forum\%20Proceeding.pdf.

Malila, Kitsana, 2011, Khorat gas sand, in The 4th Petroleum Forum-Approaching to the 21st Petroleum Concession Bidding Round, Chatuchak, Bangkok, Thailand, May 26-27, 2011, Proceedings: Department of Mineral Fuels, Ministry of Energy, 1 p., accessed December 19, 2016, at http://www.dmf. go.th/cms/assets/1/The $\% 204$ th\%20(DMF)\%20Petroleum $\% 20$ Forum \%20Proceeding.pdf.

Metcalfe, Ian, 2011, Tectonic framework and Phanerozoic evolution of Sundaland: Gondwana Research, v. 19, no. 1, p. 3-21.

Morley, C.K., 2012, Late Cretaceous-Early Paleogene tectonic development of SE Asia: Earth Science Reviews, v. 115, no. $1-2$, p. 37-75.

Morley, C.K., Ampaiwan, P., Thanudamrong, S., Kuenphan, N., and Warren, John, 2013, Development of the Khao Khwang fold and thrust belt-Implications for the geodynamic setting of Thailand and Cambodia during the Indosinian Orogeny: Journal of Asian Earth Sciences, v. 62, p. 705-719.

Racey, Andrew, 2011, Petroleum geology, chap. 13 of Ridd, M.F., Barber, A.J., and Crow, M.J., eds., The geology of Thailand: London, The Geological Society, p. 351-392.

\section{For More Information}

Assessment results are available at the USGS Energy Resources Program website at https://energy.usgs.gov.

\section{Khorat Plateau Province Assessment Team}

Christopher J. Schenk, Timothy R. Klett, Tracey J. Mercier, Thomas M. Finn, Marilyn E. Tennyson, Stephanie B. Gaswirth, Kristen R. Marra, Phuong A. Le, and Ronald M. Drake II 